\title{
The Evolution of Terminology Within the Tertiary Education System in Poland-From a Diachronic Perspective
}

\author{
Alina Szwajczuk \\ University of Szczecin, Szczecin, Poland
}

\begin{abstract}
Pursuant to the Bologna Declaration of 1999, the establishment of the European Higher Education Area has entailed some standardization within the scope of terminology pertaining to tertiary education. Even though the process has left some room for country specific terminology, with names of higher education institutions being often used in their original wording, just to avoid lack of clarity, translation of the names in question is often performed for informative and for diploma recognition purposes. The aspect of translation seems not to pose a significant problem with regard to current names of tertiary education as there exist both strict and transparent rules defined by the Polish law with regard to the naming process as well as guidelines issued by the Council of Europe determining the standardization of higher education in the countries of the Bologna Process signatories. It may, however, cause some difficulties, in the case of translation of names used in the past. The main thrust hereof is to present the way the tertiary education system in Poland developed in terms of applied terminology of proper names of higher education institutions. The analyzed issue is mostly supposed to depict restrictions within the naming process and to suggest translation into English that conforms to the currently binding Polish law and that takes into consideration the then binding laws in Poland. The legislative ground subject to the analysis is constituted by Polish acts, resolutions, and official announcements, while the period covered encompasses the time span between WWII and the present moment. The suggested translation is understood as a transfer of culture and presentation of the education system, depicted from a diachronic perspective.
\end{abstract}

Keywords: higher education, proper names, Bologna Declaration, standardization, translation studies, tertiary education

\section{Introduction}

First and foremost, it must be explicitly underlined that the Polish law is and has always been very clear in terms of name- and naming process - related provisions and restrictions. Thus, the application of the terms comprising university, polytechnic, and academy is strictly limited and governed by the Polish Law on Higher Education dated July 27, 2005. Institutions of lower prestige, including a significant number of private and vocational institutions, usually offering a narrower educational offer than Polish reputable and prestigious tertiary education institutions, mostly apply in their Polish name the term school. A similar situation is observed both within the USA and the United Kingdom. The document that presents clearly the profiles of education and names applied accordingly is The Carnegie Classification of Institutions of Higher Education, 2000. The document in question leaves no doubt that such names as university or institute are reserved and their

Alina Szwajczuk, assistant lecturer, M.A., Department of English, University of Szczecin, Szczecin, Poland. 
application appears to be rigorously observed. Within the United Kingdom, the crucial acts, which may dispel numerous doubts concerning the allegedly free, unrestrained use and inclusion of the lexeme university in reference to UK further and higher education providers, are the Further and Higher Education Act 1992 and the Teaching and Higher Education Act of 1998. The former, in part II section 77 thereof, restricts the use of the lexeme university in the title of an institution, stating that a given higher education provider may apply the name under an applicable enactment or instrument or upon the consent of the Privy Council.

The translations suggested in the paper, which simultaneously accompany the names presented, shall be viewed as a form of negotiation between the Polish law and the terminology applied in English speaking countries.

\section{Evolution of Terminology}

\section{WWII and the Post-War Period}

Analyzing the development of tertiary education in Poland, the Act of 1932 that was still binding after WWII also covered post-secondary education. The Act dated 15 March 1933 on szkoty akademickie (suggested translation: academic higher education institutions) listed, under Article 1(3), proper names that could be assigned to szkoty akademickie (suggested translation: academic higher education institutions), namely: uniwersytet (university), wszechnica ${ }^{1}$ (suggested translation: university/school), politechnika (polytechnic institute; institute of technology), akademja (suggested translation: university/academy/school), szkoła główna (suggested translation: school); restricting, at the same time, that szkoty niekademickie (non-academic higher education institutions) must not apply such names. ${ }^{2}$ Article 2 thereof listed państwowe szkoly akademickie (public/state academic higher education institutions), which included:

Uniwersytet Jagielloński w Krakowie (official translation: Jagiellonian University in Kraków),

Uniwersytet Stefana Batorego w Wilnie (suggested translation: The Stefan Batory University in Wilno),

Uniwersytet Jana Kazimierza we Lwowie (suggested translation: The Jan Kazimierz University in Lwów/Lviv),

Uniwersytet Warszawski (official translation: University of Warsaw),

Uniwersytet Poznański (suggested translation: The University of Poznań),

Politechnika Lwowska (suggested translation: The Institute of Technology in Lwów/Lviv),

Politechnika Warszawska (official translation: Warsaw University of Technology),

Szkoła Glówna Gospodarstwa Wiejskiego w Warszawie (official translation: Warsaw University of Life Sciences),

Akademia Medycyny Weterynaryjnej we Lwowie (suggested translation: The University/Academy of Veterinary Medicine in Lwów/Lviv),

Akademia Górnicza w Krakowie (suggested translation: The Academy of Mining in Kraków/Cracow), ${ }^{3}$

\footnotetext{
${ }^{1}$ Definition of wszechnica provided by SJP (p. 1175): 1. < wyższa uczelnia > (translation: higher education institution); translation provided by PWN-Oxford: university.

2 The Act binding as of 18 May 2015, i.e., the Law on Higher Education of 27 July 2005 (Ustawa z dnia 27 lipca 2005r. —Prawo o szkolnictwie wyższym) provides, in reference to university-type of educational establishments, solely for such terms as: uniwersytet, uniwersytet plus the type of a university, e.g., The University of Technology, politechnika, academia. This, undoubtedly, should be taken into account while translating names of Polish higher education institutions into English.

${ }^{3}$ Now Akademia Górnicza-Hutnicza im. Stanistawa Staszica w Krakowie (official translation: AGH University of Science and Technology).
} 
Akademia Sztuk Pięknych $w$ Krakowie (suggested translation: The Academy of Fine Arts in Kraków/Cracow),

Akademia Sztuk Pięknych w Warszawie (suggested translation: The Academy of Fine Arts in Warszawa/Warsaw),

Akademia Stomatologiczna $w$ Warszawie (suggested translation: The Academy of Dentistry in Warszawa/Warsaw; Dental Academy in Warszawa/Warsaw; Warsaw Dental Academy).

Article 55(1) provided a list of prywatne szkoty akademickie (private academic higher education institutions) including: Szkoła Główna Handlowa w Warszawie (official translation: Warsaw School of Economics) (formerly Wyższa Szkoła Handlowa), Katolicki Uniwersytet Lubelski (suggested translation: The Catholic University of Lublin), and Wolna Wszechnica Polska w Warszawie (literally: Independent/Free Polish Higher Education Institution in Warszawa; suggested translation: Independent Polish University of Warszawa/Warsaw). What needs to be mentioned here is the fact that Article 59 thereof imposed upon prywatne szkoty nieakademickie (private non-academic higher education institutions) which applied names reserved solely for szkoły akademickie (academic higher education institutions), an obligation to change the name till 31st December 1933. The Act of 22 February 1937 on prywatne szkoty wyższe (literally: private higher education schools; suggested translation: private schools of higher education) (Ustawa z dnia 22 lutego 1937r. o prywatnych szkołach wyższych), in its Article 1(1), defined prywatne szkoly wyższe (private schools of higher education) as those excluded from the Act of 15 March 1933 on szkoly akademickie (academic higher education institutions). The term szkoła wyższa (literally: higher school; suggested translation: school of higher education) shall be understood as prywatna szkoła wyższa (private schools of higher education), to which the law of the act of 1933 was not applicable. ${ }^{4}$ Further, under Article 17, the law also did not apply to seminaria duchowne (theological seminary), katolickie zakłady teologiczne (Catholic theological units/institutes) and szkoty artystyczne (schools of art), governed by Article 13(2) of the Concordat concluded between the Holy See and the Republic of Poland, executed in Rome on 10 February 1925.

The decree of October 28, 1947 on higher education (Dekret z dnia 28 października 1947 o organizacji nauki i szkolnictwa wyższego) defined, in its Article 3(1), szkolnictwo wyższe (higher education) as comprising szkoty wyższe zawodowe (schools of higher vocational education) and szkoty wyższe akademickie (academic higher education institutions/schools). Under Article 6(1), the term szkoła wyższa (school of higher education) shall be applicable solely to szkoty wyższe (plural form of szkoła wyższa), organized pursuant to the decree. The terms of: akademia, politechnika, szkoła akademicka, szkoła główna, uniwersytet, wszechnica (academy, polytechnic institute/institute of technology, academic higher education institution, university, university/school) may only be assigned to szkoty wyższe akademickie (academic higher education institutions) under the decree. The term instytut (institute) shall be reserved for państwowe placówki naukowo-badawcze (public/state research and scientific units). ${ }^{5}$ The said decree also provided for szkoly wyższe niepaństwowe (private

\footnotetext{
${ }^{4}$ Article 1(2).

5 Article 6(2) and Article 6(3).
} 
higher education institutions). ${ }^{6}$ Further, the Act dated 22 March 1951 on establishing Akademia Wojskowo-Polityczna (suggested translation: Military and Political Academy) (Ustawa z dnia 22 marca $1951 r$. o utworzeniu Akademii Wojskowo-Politycznej), classified the institution, in Article 1(2), as szkoła wyższa akademicka (literally: academic higher school; suggested translation: school of higher education). As under Article 1(4), Akademia Wojskowo-Polityczna was a military unit and the direct supervision over the higher education institution was held by the Minister of National Defense. At the same time, Wojskowa Akademia Techniczna (suggested translation: Military Technical Academy) was formed under the Act dated 22 March 1951 on establishing Wojskowa Akademia Techniczna (Ustawa z dnia 22 marca 1951r. o utworzeniu Wojskowej Akademii Technicznej), which included provisions identical with the regulations concerning Akademia Wojskowo-Polityczna (suggested translation: Military and Political Academy).

\section{The ${ }^{6} 50 \mathrm{~s}$ and $600 \mathrm{~s}$}

In the year of 1951, in pursuance with the Resolution of the Minister of Higher Education Institutions and Science as of 15 September 1951 on establishing preparatory studies at some higher education institutions (Rozporzadzenie ministra szkót wyższych i nauki z dnia 15 września 1951r. w sprawie utworzenia studiów przygotowawczych $w$ niektórych szkołach wyższych), 4-semestralne studia przygotowawcze (four-semester preparatory studies) were introduced into the system of tertiary education. The objective thereof was to prepare candidates for studying at szkoty wyższe (higher education institutions) and it was targeted at adults between 18 and 27 years of age. ${ }^{7}$ The same year also brought another amendment into the system of higher education, as the office of the Minister of Higher Education Institutions and Science was transformed into the Minister of

\footnotetext{
${ }^{6}$ Other resolutions and acts on higher education that appeared between 1947 and 1951 included:

Rozporzqdzenie Ministra Kultury i sztuki z dn. 23 grudnia 1950 w sprawie stopni zawodowych oraz warunków uzyskiwania dyplomów zawodowych $w$ wyższych szkołach artystycznych (Resolution of the Minister of Culture and Art as of 23 December 1950 on degrees and requirements for awarding professional diplomas in higher education institutions of art)

Rozporzadzenie ministra szkół wyższych i nauki z dn. 1 marca 1951 w sprawie zmian organizacyjnych w niektórych szkołach wyższych (Resolution of the Minister of Higher Education Institutions and Science as of 1 March 1951 on organizational amendments introduced at some higher education institutions)

Rozporzadzenie ministra szkół wyższych i nauki z dn. 3 marca 1951 w sprawie zmian organizacyjnych w niektórych szkołach wyższych (Resolution of the Minister of Higher Education Institutions and Science as of 3 March 1951 on organizational amendments introduced at some higher education institutions)

Rozporzqdzenie ministra szkót wyższych i nauki z dn. 22 maja 1951 w sprawie zmian organizacyjnych w niektórych szkołach wyższych (Resolution of the Minister of Higher Education Institutions and Science as of 22 May 1951 on organizational amendments introduced at some higher education institutions)

Rozporzqdzenie ministrów: szkót wyższych i nauki, oświaty, zdrowia oraz sprawiedliwości z dnia 1 czerwca 1951r. w sprawie tryby postępowania przy przyjmowaniu kandydatów na I rok studiów do szkót wyższych na rok szkolny 1951/52 (Resolution of ministers: of higher education institution and science, education, health and justice as of 1 June 1951 on the admission procedure specified for candidates for the first year of studies for the 1951/52 academic year)

Rozporządzenie ministra szkót wyższych i nauki z dnia 14 lipca 1951r. w sprawie trybu postępowania przy podejmowaniu kandydatów na pierwszy rok studiów do wieczorowych szkót inżynieryjnych na rok szkolny 1951/52 (Resolution of the Minister of Higher Education Institutions and Science as of 14 July 1951 on the admission procedure specified for candidates for the first year of studies for the 1951/52 academic year)

Ustawa z dnia 26 kwietnia 1950r. o utworzeniu urzędu Ministra Szkót Wyższych i Nauki (the Act of 26 April 1950 on establishing an office of the Minister of Higher Education Institutions and Science)

Ustawa z dnia 10 września 1956r. o przejęciu szkolnictwa zawodowego przez Ministra Oświaty (The Act of 10 September 1956 on taking over the vocational tertiary education by the Minister of Education)

Ustawa z dnia 31 marca 1965r. o stopniach naukowych i tytulach naukowych (The Act of 31 March 1965 on academic degrees and titles)

The resolutions and acts did not introduce any changes into the types of schools and terminology applied; they solely introduced the organizational and administrative amendments.

${ }^{7}$ Article 2(1), 2(3).
} 
Higher Education. ${ }^{8}$ From that moment onwards, the then minister in charge governed szkoty wyższe (higher education institutions), instytuty naukowe (scientific institutes), and other placówki naukowe (academic units). ${ }^{9}$ Further changes that were introduced into the system of tertiary education took place in 1958, when the Act of 5 November 1958 on higher education institutions (Ustawa z dnia 5 listopada 1958r. o szkołach wyższych), Article 3(1), stated that the name of szkoła wyższa (higher education institution) should include one of the following terms: uniwersytet (university), politechnika (polytechnic institute/institute of technology), academia (academy), szkoła główna (literally: central/main school), or szkoła wyższa (literally: higher school; suggested translation: school of higher education). Under Article 140, Wieczorowa Szkoła Inżynierska w Biatymstoku (literally: Evening School of Engineering in Białystok; suggested translation: (Part-time) School of Engineering in Białystok), Wieczorowa Szkoła Inżynierska w Bydgoszczy (literally: Evening School of Engineering in Bydgoszcz; suggested translation: (Part-time) School of Engineering in Bydgoszcz), Wieczorowa Szkoła Inżynierska $w$ Lublinie (literally: Evening School of Engineering in Lublin; suggested translation: (Part-time) School of Engineering in Lublin), Wieczorowa Szkoła Inżyierska w Radomiu (literally: Evening School of Engineering in Radom; suggested translation: (Part-time) School of Engineering in Radom), and Wieczorowa Szkoła Inżynierska $w$ Warszawie (literally: Evening School of Engineering in Warszawa; suggested translation: (Part-time) School of Engineering in Warszawa) were classified as wyższe szkoły zawodowe (higher vocational education institutions); stipulating at the same time, in Article 141, that separate provisions shall be binding for wyższe szkoly zawodowe. The Act of 31 March 1965 on military higher education (Ustawa z dnia 31 marca 1965r. o wyższym szkolnictwie wojskowym) determined that the term wyższe szkoty wojskowe (higher military education institutions) encompassed akademie wojskowe (military academies) and wyższe szkoły oficerskie (military schools). ${ }^{10}$ Article 2 classified akademie wojskowe (military academies) and wyższe szkoty oficerskie (military schools) as państwowe szkoty wyższe (public/state higher education institutions/schools) being simultaneously military units. Article 54 thereof enumerated akademie wojskowe (military academies) including: Akademia Obrony Narodowej (suggested translation: Academy of National Defence), Wojskowa Akademia Techniczna imienia Jarosława Dabrowskiego (suggested translation: the Jarosław Dąbrowski Military Technical Academy), and Akademia Marynarki Wojennej imienia Bohaterów Westerplatte (official translation: Polish Naval Academy of the Heroes of Wetsreplatte). The year 1965 also brought some changes with the implementation of the Act of 31 March 1965 introducing amendments to higher education institutions (Ustawa z dnia 31 marca 1965r. o zmianie ustawy o szkołach wyższych). The amendments in question provided for a change in the title of the act, replacing the phrase o szkołach wyższych (on higher education institutions) with o szkolnictwie wyższym (on higher education). Article 1(1) stated that szkolnictwo wyższe (higher education) comprised szkoty wyższe (higher education institutions/schools) and wyższe szkoty zawodowe (higher vocational education institution/school). Further, Article 3 of the 1958 act was supplemented with paragraph 1a stating that the name of wyższa szkoła zawodowa (higher vocational education institution/school) should

\footnotetext{
8 The Act of 15 December 1951 on transforming the office of the Minister of Higher Education Institutions and Science into the office of the Minister of Higher Education (Ustawa z dnia 15 grudnia 1951r. o przeksztatcaniu urzędu Ministra Szkót Wyższych $i$ Nauki w urzad Ministra Szkolnictwa Wyższego).

9 In 1956, Obwieszczenie Ministra Szkolnictwa Wyższego z dnia 10 października 1956r. w sprawie ogłoszenia jednolitego tekstu ustawy z dnia 15 grudnia 1951r. o szkolnictwie wyższym i o pracownikach nauki restated (Article 2(1)) that the Minister of Higher Education supervises szkoły wyższe (higher education institutions/schools) and szkoły wyższe niepaństwowe (non-public/private higher education institutions) that abide by provisions of the Minister of Higher Education.

10 Article 1.
} 
include the said term wyższa szkoła zawodowa (higher vocational education institution/school) or any other term indicating the type of szkola (here: the profile of the higher education institution). ${ }^{11}$

\section{The '70s and the Full List of Higher Education Institutions}

The Resolution of the Minister of Science, Higher Education and Technology as of 23 January 1975 on determining fields of studies conducted by public higher education institutions and independent research and didactic units subject to the supervision of the Minister of Science, Higher Education and Technology (Rozporzqdzenie Ministra Nauki, Szkolnictwa Wyższego i Techniki z dn. 23 stycznia 1975 r. w sprawie określenia rodzajów studiów prowadzonych przez państwowe szkoły wyższe i samodzielne placówki typu naukowo-dydaktyczne podlegle nadzorowi Ministra Nauki, Szkolnictwa Wyższego i Techniki) provided a list of państwowe szkoly wyższe (public higher education institutions/schools) and samodzielne placówki typu naukowo-dydaktycznego (independent research and didactic units) subject to the supervision of the Minister of Science, Higher Education and Technology, authorized to conduct studia magisterskie (master degree studies/second-cycle programme of studies), studia zawodowe (vocational studies), studia podyplomowe (post-graduate studies), kursy doskonalenia zawodowego (PWN translation: inservice (training) courses), as well as kursy $i$ studia specjalne (special education courses and programmes of study):

Uniwersytet Gdański (official translation: University of Gdańsk),

Uniwersytet Jagielloński (official translation: Jagiellonian University in Kraków),

Uniwersytet Ślaski w Katowicach (official translation: University of Silesia in Katowice),

Uniwersytet Marii Curie-Skłodowskiej w Lublinie (official translation: The Maria Curie-Skłodowska University in Lublin),

Uniwersytet Łódzki (official translation: University of Łódź),

Uniwersytet im. Adama Mickiewicza w Poznaniu (official translation: The Adam Mickiewicz University in Poznań),

Uniwersytet Mikołaja Kopernika w Toruniu (official translation: The Nicolaus Copernicus University in Toruń),

Uniwersytet Warszawski (official translation: University of Warsaw),

Uniwersytet Wrocławski im. Bolesława Bieruta we Wrocławiu (suggested translation: The Bolesław Bierut University in Wrocław),

Wyższa Szkoła Pedagogiczna w Bydgoszczy (suggested translation: School of Education in Bydgoszcz),

Wyższa Szkoła Pedagogiczna w Częstochowie (suggested translation: School of Education in Częstochowa),

Wyższa Szkoła Pedagogiczna w Kielcach (suggested translation: School of Education in Kielce),

Wyższa Szkoła Pedagogiczna im. Komisji Edukacji Narodowej w Krakowie (official translation: The Higher College of Teacher Training; the National Education Commission),

Wyższa Szkoła Pedagogiczna w Olsztynie (suggested translation: School of Education in Olsztyn),

Wyższa Szkoła Pedagogiczna im. Powstańców Ślaskich w Opolu (suggested translation: School of Education in Opole),

Wyższa Szkoła Pedagogiczna w Rzeszowie (suggested translation: School of Education in Rzeszów),

11 Also the term placówki naukowe (scientific units) was changed into instytucje (institutions) (amendment introduced to Article 5(2), (4) of the above mentioned 1958 act). 
Wyższa Szkoła Pedagogiczna w Siedlcach (suggested translation: School of Education in Siedlce),

Wyższa Szkoła Pedagogiczna w Stupsku (suggested translation: School of Education in Słupsk),

Wyższa Szkoła Pedagogiczna w Szczecinie (suggested translation: School of Education in Szczecin),

Wyższa Szkoła Pedagogiczna w Zielonej Górze (suggested translation: School of Education in Zielona Góra),

Państwowy Instytut Pedagogiki Specjalnej im. Marii Grzegorzewskiej w Warszawie (suggested translation: The Maria Grzegorzewska School of Special Education),

Szkoła Główna Planowania i Statystyki w Warszawie (official translation: Central School of Planning and Statistics),

Akademia Ekonomiczna im. Karola Adamieckiego w Katowicach (suggested translation: Academy of Economics in Katowice),

Akademia Ekonomiczna w Krakowie (suggested translation: Academy of Economics in Kraków),

Akademia Ekonomiczna w Poznaniu (suggested translation: Academy of Economics in Poznań),

Akademia Ekonomiczna im. Oskara Langego we Wrockawiu (suggested translation: The Oscar Lange Academy of Economics in Wrocław),

Akademia Teologii Katolickiej w Warszawie (translation by Kierzkowska \& Rybińska, 1994, p. 93: Academy of Catholic Theology in Warsaw),

Chrześcijańska Akademia Teologiczna w Warszawie (translation by Kierzkowska \& Rybińska, 1994, p. 94: Christian Theological Academy in Warsaw),

Akademia Górniczo-Hutnicza im. Stanistawa Staszica w Krakowie (official translation: AGH University of Science and Technology in Kraków),

Akademia Techniczno-Rolnicza im. Jana i Jędrzeja Śniadeckich w Bydgoszczy (suggested translation: The Jan Śniadecki and Jędrzej Śniadecki Academy of Technology and Life Sciences in Bydgoszcz),

Politechnika Białostocka (official translation: Białystok University of Technology),

Politechnika Częstochowska (official translation: Częstochowa University of Technology),

Politechnika Gdańska (official translation: Gdańsk University of Technology),

Politechnika Krakowska (suggested translation: Institute of Technology in Karków/Cracow; Cracow Institute of Technology),

Politechnika Łódzka (official translation: Technical University of Łódź),

Politechnika Poznańska (official translation: Poznań University of Technology),

Politechnika Rzeszowska im. Ignacego Lukasiewicza (translation provided by Kierzkowska \& Rybińska, 1994, p. 51: The Ignacy Łukasiewicz Rzeszów Technical University),

Politechnika Ślaska im. Wincentego Pstrowskiego w Gliwicach (suggested translation: The Wincent Pol Institute of Technology in Gliwice),

Politechnika Świętokrzyska (official translation: Kielce University of Technology),

Politechnika Szczecińska (suggested translation: Institute of Technology in Szczecin),

Politechnika Warszawska (official translation: Warsaw University of Technology),

Politechnika Wrocławska (official translation: Wrocław University of Technology),

Akademia Rolnicza w Krakowie (suggested translation: The Agricultural Academy in Kraków),

Akademia Rolnicza w Lublinie (suggested translation: The Agricultural Academy in Lublin), 
Akademia Rolniczo-Techniczna w Olsztynie (suggested translation: The Agricultural and Technical Academy in Lublin),

Akademia Rolnicza w Poznaniu (suggested translation: The Agricultural Academy in Poznań), Akademia Rolnicza w Szczecinie (suggested translation: The Agricultural Academy in Szczecin), Akademia Rolnicza w Warszawie (suggested translation: The Agricultural Academy in Warszawa/Warsaw),

Akademia Rolnicza we Wrockawiu (suggested translation: The Agricultural Academy in Wrocław).

Wyższa Szkoła Inżynierska w Koszalinie (suggested translation: School of Engineering in Koszalin),

Wyższa Szkoła Inżynierska w Lublinie (suggested translation: School of Engineering in Lublin),

Wyższa Szkoła Inżynierska w Opolu (suggested translation: School of Engineering in Opole),

Wyższa Szkoła Inżynierska im. Jurija Gagarina w Zielonej Górze (suggested translation: The Jurij Gagarin School of Engineering in Koszalin).

\section{The '80s and Military Schools and Academies}

The legislative basis that followed was the Act of 4 May 1982 on higher education (Ustawa $z$ dnia 4 maja 1982r. o szkolnictwie wyższym) $)^{12}$ where, in its Article 1(1), the act stated that: "Higher education institutions are state organizational units, established to conduct academic research, provide education, and socialist upbringing of students in conformity with the Constitution of the Polish People's Republic". ${ }^{13}$ The act was not applicable to higher education institutions remaining under the supervision of the Minister of National Defense and the Minister of Internal Affairs (Article 5(1)). Article 5(2) thereof stated that wyższe szkoty teologiczne (higher education institutions for theological purposes/higher theological education institutions) were governed by Church authorities. ${ }^{14}$ The chapter no. 2, Article 6(2), stated that "the law on establishing a higher education institution shall specify its name, registered office and a general scope of its activity as well as supreme and central state administrative body conducting supervision over its activity". The Act of 16 July 1987 on amendments to the Law on Higher Military Education (Ustawa z dnia 16 lipca 1987r. o zmianie ustawy o wyższym szkolnictwie wojskowym $)^{15}$ introduced, in Article 1, an amendment to Article 1(1) of the Act of 31 March 1965 on Higher Military Education (Ustawa z dnia 31 marca 1965r. o wyższym szkolnictwie wojskowym), stating that wyższe szkoty wojskowe (higher education institutions for military purposes/ higher military education institutions) comprised akademie woskowe (military academies) and wyższe szkoty oficerskie (schools of higher military education). Article 32(1) stated that akademie wojskowe (military academies) offered higher education studies while wyższe szkoty oficerskie (schools of higher military education) offered higher vocational studies within the area of science or scientific disciplines covered by a field of study of a school of higher military education, as well as scientific research in those areas and disciplines. Under Article 55, the act enumerated the following akademie wojskowe (military academies):

\footnotetext{
12 Entered into force on 1 September 1982, signed by the Chairman of the State Council: H. Jabłoński, Secretary of the State Council: E. Duda.

${ }_{13}$ Article 5(3) stated that the act was also applicable to non-public higher education institutions provided the statutes of the institutions in question did not state otherwise.

${ }^{14}$ Except for uczelnie papieskie (papal supremacy/catholic higher education institutions) and seminaria duchowne (theological seminaries) (under Article 5(4)).

15 Entered into force on 1 October 1987, signed by the Chairman of the State Council: W. Jaruzelski, Secretary of the State Council: Z. Surowiec.
} 
Akademia Sztabu Generalnego WP imienia Generała Broni Karola Świerczewskiego (suggested translation: the Karol Świerczewski Academy of the General Staff of the Polish Army),

Wojskowa Akademia Polityczna imienia Feliksa Dzierżyńskiego (suggested translation: The Feliks Dzierżyński Political Military Academy),

Wojskowa Akademia Techniczna imienia Jarostawa Dabrowskiego (suggested translation: The Jarosław Dąbrowski Military Technical Academy),

Wojskowa Akademia Medyczna imienia Generała Dywizji Bolesława Szareckiego (suggested translation: The Bolesław Szarecki Military Medical Academy),

Akademia Marynarki Wojennej imienia Bohaterów Westerplatte (official translation: Polish Naval Academy of the Heroes of Westerplatte).

\section{The '90s and the Currently Binding Law on Higher Education}

The act that followed, pertaining to higher education was the Act of 1990 (Ustawa $z$ dnia 12 września 1990 o szkolnictwie wyżsym). Article 1(1) thereof stated that the act was binding for state higher education institutions except for higher education institutions the statutes of which were stipulated by the act on higher military education and the act on higher vocational schools. Article 1(2) further determined that the act was also applicable to non-public higher education institutions, provided the provisions of the act or other acts did not state otherwise. The act did not apply to (Article 1(3)) higher education institutions and seminaries maintained by the Catholic Church except for Katolicki Uniwersytet Lubelski (Catholic University of Lublin), as well as higher education institutions and seminaries maintained by other churches and denomination centers unless provided otherwise by respective acts. Article 2(1) applied the term uczelnie (higher education institutions) for szkoły wyższe (schools of higher education). ${ }^{16}$

The year of 1997 introduced the Act of 26 June 1997 on wyższe szkoty zawodowe (schools of higher vocational education) (Ustawa z dnia 26 czerwca 1997r. o wyższych szkołach zawodowych), which, under Article 1(1), was applicable to państwowe wyższe szkoły zawodowe (public/state higher vocational education schools) and, under Article 2(1), niepaństwowe wyższe szkoły zawodowe (non-public higher vocational education schools), provided that provisions of any school in question or provisions of other acts did not provide otherwise. Art. 2.1 classified państwowe and niepaństwowe wyższe szkoly zawodowe (public and non-public higher vocational education institutions/schools) as uczelnie zawodowe (non-academic higher education institutions).

Finally, the Law on Higher Education of 27 July 2005 (Ustawa z dnia 27 lipca 2005r. Prawo o szkolnictwie wyższym) was applicable to publiczne and niepubliczne szkoty wyższe (public and non-public higher education institutions) (Article 1(1)), excluding szkoly wyższe (higher education colleges/schools) and seminaries maintained by the Catholic Church and denomination centers except for Katolicki Uniwersytet Lubelski (Catholic University of Lublin) (Article 1(2)). The act differed significantly from the previously adopted acts as it introduced, inter alia, the following definitions ${ }^{17}$ :

\footnotetext{
${ }^{16}$ The act that followed, Ustawa z dnia 24 lipca 1992r. o zmianie ustawy o szkolnictwie wyżm, did not introduce any amendments concerning the types of schools or names.

17 The definitions provided in Polish constitute direct quotes from the law in question. Source of the English version: http://www.nauka.gov.pl/g2/oryginal/2013_12/d687905792f5ff6a3ecf84d7df4f8e57.pdf.
} 
Article 2(1)

Uczelnia akademicka-uczelnia prowadzqca badania naukowe, w której co najmniej jedna jednostka organizacyjna posiada uprawnienie do nadawania stopnia naukowego doktora (university higher education institution - shall mean an establishment providing degree-level education with a minimum one academic unit authorized to confer the degree of doktor)

Uczelnia zawodowa-uczelnia prowadzaca studia pierwszego lub drugiego stopnia albo jednolite studia magisterskie nieposiadajaca uprawnienia do nadawania stopnia naukowego doktora (non-university higher education institution-shall mean an establishment providing first, second and long cycle programmes which does not have the authority to confer the degree of doktor)

Uczelnia wojskowa-uczelnia publiczna nadzorowana przez Ministra Obrony Narodowej (military higher education institution - shall mean a public higher education institution under the supervision of the Minister of National Defence)

Uczelnia służb państwowych-uczelnia publiczna nadzorowana przez ministra właściwego do spraw kultury i ochrony dziedzictwa narodowego (public services higher education institution-shall mean a public higher education institution under the supervision of the minister competent for internal affairs)

Uczelnia artystyczna-uczelnia publiczna nadzorowana przez ministra właściwego do spraw kultury $i$ ochrony dziedzictwa narodowego (higher education institution for the arts-shall mean a public higher education institution under the supervision of the minister competent for culture and national heritage)

Uczelnia medyczna-uczelnia publiczna nadzorowana przez ministra wtaściwego do spraw zdrowia (higher education institution for medical studies-shall mean a public higher education institution under the supervision of the minister competent for health)

Uczelnia morska-uczelnia publiczna nadzorowana przez ministra właściwego do spraw gospodarki morskiej (higher education institution for maritime studies-shall mean a public higher education institution under the supervision of the minister competent for maritime economy)

The act that followed, which exerted a significant impact on the shape of the Polish education system was the Law of November 5, 2009 on the amendment to the act—Law on Higher Education of 2005 (Ustawa z dnia 5 listopada 2009r. o zmianie ustawy-Prawo o szkolnictwie wyższym $)^{18}$ as it supplemented the former act with Article 261(a)(1) stating that: "A minister competent for higher education may, by passing a resolution and upon the request of a governing body, 1) transform publiczna szkota pomaturalna (public post-secondary school), kolegium nauczycielskie (teacher training college), nauczycielskie kolegium języków obcych (foreign language teacher training college), and kolegium pracowników stużb spolecznych (college of social workers) into publiczna uczelnia zawodowa (public non-university higher education institution)".

\section{Conclusion}

The paper presented the evolution of names of higher education institutions in Poland within the period between WWWII and the year 2017 with the Law on Higher Education as of 27 July 2005 that is still binding. The analysis was based on Polish acts and resolutions. The main goal of the analysis was to present strict and transparent provisions related to the naming process that do affect translation required for informative -, diploma recognition - or historical purposes. The translations suggested shall not be deemed as binding but

${ }^{18}$ Adopted by the late President of the Republic of Poland L. Kaczyński. 
shall act as an invitation to devote more attention to onomastics and translation studies with regard to terminology applied in the past.

\section{References}

Bologna Declaration of 19 June 1999. Retrieved from https://www.eurashe.eu/library/bologna_1999_bologna-declaration-pdf/

Budapest-Vienna Declaration on the European Higher Education Area. (March 12, 2010). Retrieved from https://wissenschaft.bmwfw.gv.at/fileadmin/user_upload/Bologna_Grundsatzdok/Budapest_Vienna_2010.pdf

Convention on the Recognition of Qualifications concerning Higher Education in the European Region, Lisbon11.IV.1997. Retrieved from https://rm.coe.int/CoERMPublicCommonSearchServices/DisplayDCTMContent?documentId=090000168007f2c7

Dekret z dnia 28 października 1947 o organizacji nauki i szkolnictwa wyższego. Retrieved from http://isap.sejm.gov.pl/DetailsServlet?id=WDU19470660415

Education Reform Act 1988. Retrieved from http://www.legislation.gov.uk/ukpga/1988/40/contents English version retrieved from http://www.nauka.gov.pl/g2/oryginal/2013_12/d687905792f5ff6a3ecf84d7df4f8e57.pdf

Guidelines for Completion of the Diploma Supplement. Retrieved from http://www.europass.ie/europass/documents/DiplomaSupplementNationalGuidelines-August2009.pdf

Higher Education Act 1998. Retrieved from http://www.legislation.gov.uk/ukpga/2004/8/contents

Kierzkowska, D. (red., 2005). Kodeks tlumacza przysięglego z komentarzem. Warszawa: Wydawnictwo TEPIS.

Kierzkowska, D., \& Rybińska, Z. (1994). Polskie Uniwersytety i Szkoty, Polish Universities and Schools Polterm Glossary No. 5. Warszawa: Polskie Towarzystwo Tłumaczy Ekonomicznych, Prawniczych i Sądowych.

Regulation of the Minister of Science and Higher Education of 19th August 2015 on the nostrification of higher education diplomas obtained abroad and on confirmation of completion of higher education studies at a given level of education. Retrieved from http://www.nauka.gov.p1/g2/oryginal/2015_10/793a27442c36c4773f91dea86e1b5ac3.pdf

Rozporządzenie Ministra Kultury i Sztuki z dnia 23 grudnia 1950r. w sprawie stopni zawodowych oraz warunków uzyskiwania dyplomów zawodowych w wyższych szkołach artystycznych. Retrieved from http://isap.sejm.gov.pl/DetailsServlet?id=WDU19510140117\&min=1

Rozporządzenie Ministra Nauki, Szkolnictwa Wyższego i Techniki z dn. 23 stycznia 1975 r. w sprawie określenia rodzajów studiów prowadzonych przez państwowe szkoły wyższe i samodzielne placówki typu naukowo-dydaktyczne podległe nadzorowi Ministra Nauki, Szkolnictwa Wyższego i Techniki. Retrieved from http://isip.sejm.gov.pl/KeyWordServlet?viewName=thasP\&passName=plac\%C3\%B3wka\%20naukowa

Rozporządzenie Ministra Szkół Wyższych i Nauki z dnia 1 marca 1951r. w sprawie zmian organizacyjnych w niektórych szkołach wyższych. Retrieved from http://dziennikustaw.gov.pl/du/1951/s/14/113

Rozporządzenie Ministra Szkół Wyższych i Nauki z dnia 14 lipca 1951r. w sprawie trybu postępowania przy przyjmowaniu kandydatów na pierwszy rok studiów do wieczorowych szkół inżynierskich na rok szkolny 1951/52. Retrieved from http://isap.sejm.gov.pl/DetailsServlet?id=WDU19510400305\&min=1

Rozporządzenie Ministra Szkół Wyższych i Nauki z dnia 15 września 1951r. w sprawie utworzenia studiów przygotowawczych w niektórych szkołach wyższych. Retrieved from http://dziennikustaw.gov.pl/du/1951/s/48/355

Rozporządzenie Ministra Szkół Wyższych i Nauki z dnia 22 maja 1951r. w sprawie zmian organizacyjnych w niektórych szkołach wyższych. Retrieved from http://dziennikustaw.gov.pl/du/1951/s/31/244

Rozporządzenie Ministra Szkół Wyższych i Nauki z dnia 3 marca 1951r. w sprawie zmian organizacyjnych w niektórych szkołach wyższych. Retrieved from http://dziennikustaw.gov.pl/du/1951/s/14/114

Rozporządzenie Ministrów: Szkół Wyższych i Nauki, Oświaty, Zdrowia oraz Sprawiedliwości z dnia 1 czerwca 1951r. w sprawie trybu postępowania przy przyjmowaniu kandydatów na I rok studiów do szkół wyższych na rok szkolny 1951/52. Retrieved from http://dziennikustaw.gov.pl/du/1951/s/31/246

Rozporządzenie Rady Ministrów z dnia 23 marca 1967r. w sprawie utworzenia wyższych szkół oficerskich. Retrieved from http://isap.sejm.gov.pl/DetailsServlet?id=WDU19670150065

The Carnegie Classification of Institutions of Higher Education. (2000). Retrieved from $\mathrm{http}: / /$ carnegieclassifications.iu.edu/downloads/2000_edition_data_printable.pdf

Ustawa z dnia 10 września 1956r. o przejęciu szkolnictwa zawodowego przez Ministra w Oświaty. Retrieved from http://isap.sejm.gov.pl/VolumeServlet?type=wdu\&rok=1956\&numer=041 
$\begin{array}{llllllllll}\text { Ustawa } & \mathrm{z} & \text { dnia } & 11 & \text { marca } & 1932 & \text { r. } & \text { o } & \text { ustroju } & \text { szkolnictwa. }\end{array}$ http://isap.sejm.gov.pl/DetailsServlet?id=WDU19320380389

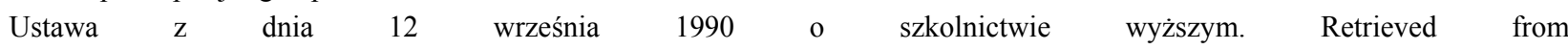
http://isap.sejm.gov.pl/DetailsServlet?id=WDU19900650385

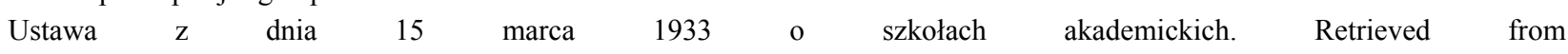
http://isap.sejm.gov.pl/VolumeServlet?type=wdu\&rok=1933\&numer=029

Ustawa z dnia 16 lipca 1987r. o zmianie ustawy o wyższym szkolnictwie wojskowym. Retrieved from http://dziennikustaw.gov.pl/du/1987/s/22/128

Ustawa z dnia 22 lutego 1937r. o prywatnych szkołach wyższych. Retrieved from http://isap.sejm.gov.pl/DetailsServlet?id=WDU19370130089

Ustawa $\mathrm{z}$ dnia 22 marca 1951r. o utworzeniu Akademii Wojskowo-Politycznej. Retrieved from http://dziennikustaw.gov.pl/du/1951/s/17/135

Ustawa z dnia 22 marca 1951r. o utworzeniu Wojskowej Akademii Technicznej. Retrieved from http://dziennikustaw.gov.pl/du/1951/s/17/136

Ustawa $\mathrm{z}$ dnia 24 lipca 1992r. o zmianie ustawy o szkolnictwie wyższym. Retrieved from http://dziennikustaw.gov.pl/du/1992/s/63/314

Ustawa z dnia 26 czerwca 1997r. o wyższych szkołach zawodowych. Retrieved from http://isap.sejm.gov.pl/DetailsServlet?id=WDU19970960590

Ustawa z dnia 26 kwietnia 1950r. o utworzeniu urzędu Ministra Szkół Wyższych i Nauki. Retrieved from http://dziennikustaw.gov.pl/du/1950/s/21/181

Ustawa z dnia 27 lipca 2005 r. Prawo o szkolnictwie wyższym. Retrieved from http://isip.sejm.gov.pl/DetailsServlet?id=WDU20051641365

Ustawa $\mathrm{z}$ dnia 31 marca 1965r. o stopniach naukowych i tytułach naukowych. Retrieved from http://isap.sejm.gov.pl/VolumeServlet?type=wdu\&rok=1965\&numer=014

Ustawa $\mathrm{z}$ dnia 31 marca 1965r. o wyższym szkolnictwie wojskowym. Retrieved from http://isap.sejm.gov.pl/DetailsServlet?id=WDU19650140102

Ustawa z dnia 31 marca 1965r. o zmianie ustawy o szkołach wyższych. Retrieved from http://isap.sejm.gov.pl/VolumeServlet?type=wdu\&rok=1965\&numer=014

Ustawa z dnia 4 maja 1982r. o szkolnictwie wyższym. Retrieved from http://dziennikustaw.gov.pl/du/1982/s/14/113

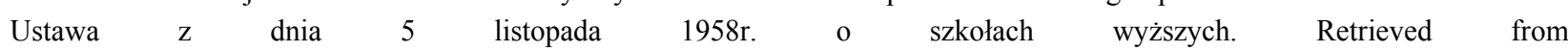
http://isap.sejm.gov.pl/VolumeServlet?type=wdu\&rok=1958\&numer=068

Ustawa $\mathrm{z}$ dnia 5 listopada 2009r. o zmianie ustawy -Prawo o szkolnictwie wyższym. Retrieved from http://isap.sejm.gov.pl/DetailsServlet?id=WDU20092021553

\section{Dictionaries}

Stownik Języka Polskiego PWN (A Dictionary of Polish). Retrieved from http://sjp.pwn.pl/

Wielki słownik angielsko-polski i polsko-angielski PWN-Oxford (A Dictionary of English and Polish). Wydawnictwo Naukowe PWN. 